\title{
Bakteri dominan di dalam saluran akar gigi nekrosis (Dominant bacteria in root canal of necrotic teeth)
}

\author{
${ }^{1}$ Irfan Fauzy Yamin, ${ }^{2}$ Nurhayaty Natsir \\ ${ }^{1}$ Mahasiswa tahap profesi \\ ${ }^{2}$ Bagian Konservasi Gigi \\ Fakultas Kedokteran Gigi Universitas Hasanuddin \\ Makassar, Indonesia
}

\begin{abstract}
One disease that often affects the pulp is necrotic teeth, which are caused by some irritants. Most major irritants are microbes, such as bacteria. This study aimed to determine the type of bacteria in the necrotic root canal. Samples were obtained from fifteen patients with necrotic teeth in Conservation Clinic of Dental Hospital, Faculty of Dentistry, Hasanuddin University. Specimens of bacteria from samples taken using paper points were inserted into the root canal. The specimens identified in the Laboratory of Microbiology, Faculty of Medicine. The results showed that there are seven types of bacteria that vary in number, most are gram-positive facultative anaerobic bacteria Actinomyces spp. It was concluded that Actinomyces spp. is the dominant species of bacteria on the necrotic tooth root canal.
\end{abstract}

Keywords: bacteria, root canals, necrotic teeth

\begin{abstract}
ABSTRAK
Salah satu penyakit pulpa yang sering diderita adalah gigi nekrosis, yang yang disebabkan oleh beberapa iritan. Iritan yang paling utama adalah mikroba, seperti bakteri. Penelitian ini dimaksudkan untuk mengetahui jenis bakteri pada saluran akar gigi nekrosis. Sampel diperoleh dari lima belas pasien dengan gigi nekrosis di Klinik Bagian Konservasi Gigi Rumah Sakit Gigi dan Mulut Fakultas Kedokteran Gigi Universitas Hasanuddin. Spesimen bakteri dari sampel diambil dengan menggunakan paper point yang dimasukkan ke dalam saluran akar. Spesimen bakteri diidentifikasi di Laboratorium Mikrobiologi Fakultas Kedokteran Universitas Hasanuddin. Hasil yang diperoleh menunjuk terdapat tujuh jenis bakteri yang bervariasi jumlahnya, terbanyak adalah bakteri anaerob fakultatif gram positif Actinomyces spp. Disimpulkan bahwa Actinomyces spp. merupakan jenis bakteri yang dominan pada saluran akar gigi nekrosis.
\end{abstract}

Kata kunci: bakteri, saluran akar, gigi nekrosis

Koresponden: Nurhayati Natsir,_E-mail: nurhayati_natsirrr@yahoo.co.id

\section{PENDAHULUAN}

Jaringan pulpa merupakan suatu jaringan ikat pada gigi yang tidak mempunyai sirkulasi darah kolateral. Jaringan pulpa berada pada suatu ruangan yang dibatasi oleh dinding dentin yang keras. ${ }^{1}$ Pulpa memiliki beberapa fungsi, salah satunya adalah fungsi formatif. Fungsi formatif yang merupakan fungsi utama jaringan pulpa, diperankan oleh odontoblas untuk membentuk dentin tersier sebagai tanggapan terhadap berbagai rangsangan berupa iritan mikroba, iritan mekanik, maupun iritan kimia. ${ }^{1,2}$

Iritan mikroba merupakan sumber utama iritasi pada jaringan pulpa gigi yang meliputi bakteri yang terdapat pada karies. Karies lanjut lambat laun akan mencapai pulpa, mengakibatkan penyakit pulpa. ${ }^{1,3}$

Penyakit pulpa menduduki urutan ketujuh dari sepuluh penyakit terbanyak pada pasien rawat jalan pengunjung rumah sakit di Indonesia tahun 2010 dengan jumlah kunjungan sebanyak 163.211 pasien. Sedangkan untuk di Kota Makassar, penyakit pulpa berada pada urutan kedelapan dari sepuluh penyakit utama untuk semua golongan umur di Kota Makassar pada tahun 2007 dengan jumlah penderita sebanyak 23.253 orang. Data tersebut membuktikan bahwa penyakit pulpa merupakan penyakit gigi dan mulut yang utama dan terbanyak diderita oleh masyarakat di Indonesia, khususnya Kota Makassar. ${ }^{4,5}$

Penyakit pulpa pada dasarnya diawali karena adanya invasi bakteri pada jaringan pulpa oleh karena karies. Invasibakteri yang telah mencapai pulpa akan mengakibatkan jaringan pulpa terinflamasi namun tetap vital dalam beberapa waktu atau akan cepat menjadi nekrosis. Bakteri tersebut akan menginvasi pulpa yang nekrosis, bereproduksi, dan menginfeksi saluran akar. ${ }^{1}$

Walaupun penyebab utama dari penyakit pulpa khususnya nekrosis adalah iritan mikroba dari karies, yaitu bakteri S.mutans dan Lactobacillus spp., tidak begitu berperan dalam perkembangan nekrosis pulpa. Hal tersebut disebabkan ketika pulpa terbuka oleh karena karies, banyak spesies bakteri oportunis yang menginvasi dan berkoloni di jaringan pulpa yang nekrosis serta memungkinkan sistem dalam jaringan pulpabersifatselektifdalammenentukan bakteri yang mendominasi jaringan pulpa yang nekrosis. ${ }^{1}$

Berdasarkanhal-hal tersebut, pengetahuan tentang bakteri merupakan hal yang penting agar patogenesis penyakit pulpa dapat lebih dipahami. Selain itu, 
pengetahuan mengenai bakteri juga sangat penting dalam perawatan endodontik yang akan diberikan. Hal tersebutmenunjukkan bahwa pengetahuan yang menyeluruh dari bakteri pada saluran akar terkait dengan penyakit pulpa merupakan dasar tercapainya keberhasilan perawatan endodontik, yaitu untuk menghilangkan bakteri sehingga tidak menginfeksi kembali saluran akar. ${ }^{1,6}$ Karena itu, perlu diketahui jenis bakteri yang dominan pada penyakit pulpa khususnya gigi nekrosis melalui identifikasi bakteri.

\section{BAHAN DAN METODE}

Penelitian observasi deskriptif dengan desain penelitian cross-sectional dilakukan di Klinik Bagian Konservasi Gigi Rumah Sakit Gigi Mulut Fakultas Kedokteran Gigi Universitas Hasanuddin Makassar pada bulan Juni-Oktober 2012. Sampel penelitian ini adalah pasien dengan gigi nekrosis yang memenuhi kriteriainklusi berupa pasien berusia 15-35 tahun, gigi nekrosis yang disebabkan oleh karies, gigi nekrosis dengan perforasi atap pulpa, gigi nekrosis tanpa kelainan periapikal, gigi nekrosis hanya satu gigi bagi satu pasien. Pasien yang tidak bersedia mengikuti prosedur penelitian, pasien yang dalam enam bulan terakhir mengkonsumsi antibiotik dan menderita penyakit degeneratif diekslusi. Diperoleh 15 pasien yang dijadikan sebagai sampel pada penelitian ini.

Spesimen bakteri diambil sebelum dilakukan preparasi saluran akar. Gigi yang terlibat diisolasi, lesi karies yang masih ada dihilangkan, lalu dibuat akses ke rongga pulpa dengan menggunakan round bur steril. Paper point steril dimasukkan ke saluran akar gigi tersebut tinggal selama 60 detik untuk pengambilan spesimen bakteri. ${ }^{7,8}$ Paper point yang telah mengandung spesimen bakteri dimasukkan ke dalam media transpor lalu ditutup rapat, dan dibawa ke Laboratorium Mikrobiologi untuk diidentifikasi.

Spesimen bakteri untuk setiap sampel dilakukan pengenceran sebanyak lima kali, dipindahkan ke cawan petri yang berisi media BHI B, dan diinkubasi selama 24 jam pada temperatur $37^{\circ} \mathrm{C}$. Setelah itu, isolasi bakteri dengan mengambil koloni bakteri menggunakan ose steril lalu digoreskan pada nutrient agar dan agar Mac Conkey dan diinkubasi kembali selama 24 jam pada temperatur $37^{\circ} \mathrm{C}$.

Bakteri yang telah diisolasi, diidentifikasi dengan pewarnaan Gram, dilakukan uji biokimia, inkubasi kembali selama 24 jam pada suhu $37^{\circ} \mathrm{C}$. Data pada penelitian ini dideskriptifkan secara sederhana dan disajikan dalam bentuk tabel.

\section{HASIL}

Pada penelitian ini, terjaring sampel sebanyak lima belas orang dengan rentang usia 15-35 tahun, dan perempuan lebih banyak dibandingkan laki-laki (Tabel 1).

Tabel 1 Distribusi sampel penelitian berdasarkan usia dan jenis kelamin

\begin{tabular}{ccc}
\hline \multicolumn{1}{c}{ Karakteristik sampel } & Jumlah Sampel & $\%$ \\
\hline Usia & & \\
15-21 tahun & 10 & 66,67 \\
22-28 tahun & 2 & 13,33 \\
29-35 tahun & 3 & 20 \\
Jenis Kelamin & & \\
Laki-laki & 4 & 26,67 \\
Perempuan & 11 & 73,33 \\
\hline Total Sampel & 15 & 100 \\
\hline
\end{tabular}

Tabel 2 Distribusi sampel penelitian berdasarkan gigi yang terlibat

\begin{tabular}{|c|c|c|c|c|c|}
\hline \multirow{2}{*}{ Rahang } & \multicolumn{4}{|c|}{ Jenis Gigi } & \multirow{2}{*}{ Total } \\
\hline & I & $\mathrm{C}$ & $\mathrm{P}$ & $\mathrm{M}$ & \\
\hline Atas & 3 & 1 & 4 & 3 & 11 \\
\hline Bawah & - & - & 1 & 3 & 4 \\
\hline Total & 3 & 1 & 5 & 6 & 15 \\
\hline
\end{tabular}

Gigi yang paling banyak pada sampel penelitian ini adalah gigi premolar rahang atas sebanyak empat gigi,sementarayang paling sedikitadalah gigi kaninus rahang atas dan gigi premolar rahang bawah yang jumlahnya hanya satu gigi. Tidak ada gigi insisivus dan kaninus rahang bawah yang dirawat pada sampel penelitian ini (Tabel 2).

Tabel 3 Pengelompokan bakteri pada saluran akar gigi nekrosis berdasarkan media tumbuh dan pewarnaan gram

\begin{tabular}{lcc}
\hline \multicolumn{1}{c}{ Kelompok bakteri } & $\begin{array}{c}\text { Jumlah } \\
\text { Spesimen }\end{array}$ & $\begin{array}{c}\text { Presentase } \\
(\%)\end{array}$ \\
\hline Media Tumbuh & 3 & 42,86 \\
Bakteri aerob & 4 & 57,14 \\
Bakteri anaerob fakultatif & & \\
\hline Pewarnaan Gram & 4 & 57,14 \\
Bakteri Gram Negatif & 3 & 42,86 \\
$\quad$ Bakteri Gram Positif & 7 & 100 \\
\hline Total & \\
\hline
\end{tabular}

Bakteri yang teridentifikasi sebanyak tujuh jenis. Berdasarkan media tumbuhnya, diidentifiasi bakteri anaerob fakultatif sebanyak $57,14 \%$ dan bakteri aerob sebanyak $42,86 \%$, sedangkan berdasarkan pewarnaan Gram, 57,14\% merupakan bakteri Gram negatif, sedangkan bakteri Gram positif sebanyak $42,86 \%$ (Tabel 3).

Jumlah bakteri yang didapatkan dari seluruh sampel penelitian sebanyak dua puluh, yang jenisnya adalah Acinetobacter calcoaceticus, Pseudomonas aeruginosa, Staphylococcus aureus, Proteus vulgaris, Klebsiella pneumoniae, dan Actinomyces spp., serta Streptococcus spp. Jenis bakteri yang paling banyak 
Tabel 4 Jenis bakteri pada saluran akar gigi nekrosis

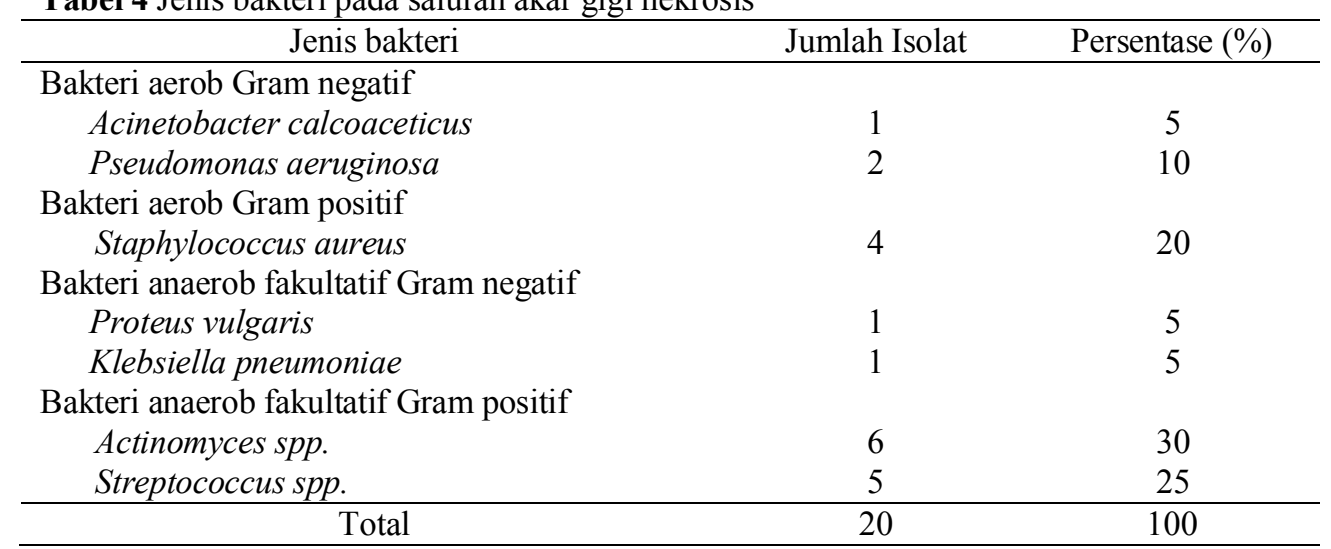

Jumlah bakteri yang didapatkan dari penelitian ini adalah dua puluh, yang jenisnya adalah Acinetobacter calcoaceticus, P.aeruginosa, Staphylococcus aureus, Proteus vulgaris, K.pneumoniae, Actinomyces spp., dan Streptococcus spp. Bakteri yang paling banyak teridentifikasi adalahbakteri Actinomyces spp. (30\%), Streptococcus spp. (25\%), Staphylococcus aureus (20\%), P.aeruginosa (10\%), Proteus vulgaris (5\%), Acinetobacter calcoaceticus (5\%), dan K.pneumoniae (5\%). Tampakbakteri anaerob fakultatif Gram positif adalah bakteri yang paling dominan pada penelitian ini (Tabel 4)

\section{PEMBAHASAN}

Bakteri yang terdapat dalam karies merupakan sumber utama iritasi terhadapjaringan pulpa. Bakteri akan memproduksi toksin yang akan berpenetrasi ke dalam pulpa melalui tubulus dentinalis sehingga sel-sel inflamasi kronik seperti makrofag, limfosit, dan sel plasma berinfiltrasi secara lokal pada jaringan pulpa. ${ }^{1}$

Inflamasi pulpa yang mengakibatkan penyakit pulpa merupakan infeksi polimikroba, yaitu infeksi yang disebabkan oleh berbagai jenis bakteri. Pada penelitian ini $57,14 \%$ bakteri yang terdapat pada saluran akar gigi nekrosis adalah bakteri anaerob fakultatif, sedangkan bakteri aerob sebanyak $42,86 \%$. Hasil penelitian Rani dan Chopra $^{10}$ dan Ercan $^{7}$ juga menyatakan $53 \%$ bakteri pada saluran akar nekrosis merupakan bakteri anaerob fakultatif. Berdasarkan hal tersebut, bakteri-bakteri anaerob fakultatif umum ditemukan pada saluran akar gigi nekrosis.

Bakteri anaerob fakultatifdapat tumbuh pada kondisi dengan ada atau tidak adanya oksigen, sedangkan bakteri aerob merupakan bakteriyang dapat tumbuh dengan adanya oksigen. ${ }^{9}$ Pada saluran akar nekrosis, tegangan oksigen lebih rendah dibandingkan rongga pulpa sehingga bakteri anaerob fakultatif lebih umum ditemukan pada saluran akar nekrosis dibandingkan bakteri aerob. ${ }^{11}$
Kelompok bakteri Gram negatif lebih banyak dibandingkan dengan bakteri gram positif. Hasil ini tidak sama dengan Ercan ${ }^{7}$ yang menyatakan $62,4 \%$ infeksi saluran akar gigi didominasi oleh bakteri Gram positif. Menurut Rani dan Chopra, ${ }^{10}$ bakteri yang banyak ditemukan pada saluran akar gigi nonvital adalah bakteri Gram positif sebanyak 50,73\%. Berdasarkan penelitian itu, terbukti ada perbedaan bakteri yang ditemukan pada saluran akar nekrosis dari segi pewarnaan Gram.

Bakteri Gram negatif dapat sebagai proteolitik dan kolagenolitik yang dapat mengubah struktur jaringan ikat pulpa. Selain itu, bakteri gramnegatifjuga mampu meningkatkan patogenesis dengan cara melepaskan endotoksin dalam bentuk lipopolisakarida yang dapat berinteraksi dengan sel-sel inflamasi yang memicu reaksi inflamasi pada gigi nekrosis. Oleh karena itu, bakteri Gram negatif lebih bersifat bersifat patogen dibandingkan bakteri Gram positif sehingga lebih banyak ditemukan di dalam saluran akar gigi yang nekrosis. $^{11}$

Berdasarkan hasil penelitian, bakteri yang teridentifikasi dari saluran akar gigi yang nekrosis sebanyak tujuh jenis bakteri, yaitu Acinetobacter calcoaceticus, P.aeruginosa, Staphylococcus aureus, Proteus vulgaris, K.pneumoniae, Actinomyces spp., dan Streptococcus spp. Hal ini membuktikan bahwa bakteri pada gigi nekrosis merupakan bakteri yang secara deskriptif berbeda. Perbedaan tersebut oleh karena saluran akar gigi nekrosis merupakan tempat invasi bakteri yang memiliki banyak sumber nutrisi sehingga memungkinkan beberapajenis bakteri yang berbeda dapat tumbuh. ${ }^{12}$

Walaupun nekrosis pada penelitian ini disebabkan oleh karies gigi, bakteri Lactobacillus spp. yang terdapat pada karies tidak ditemukan pada saluran akar gigi nekrosis. Namun, bakteri Streptococcus spp masih ditemukan saluran akar gigi nekrosis. Hal ini membuktikan jaringan pulpa bersifat selektif 
sehingga memungkinkan pertumbuhan jenis bakteri tertentu. ${ }^{1,3}$

Pertumbuhan jenis bakteri pada gigi nekrosis dipengaruhi adanya nutrisi pada jaringan nekrosis, tegangan oksigen yang rendah, dan interaksi antar bakteri. Nutrisi yang menjadi media tumbuh bakteri berasal dari hasil reaksi inflamasi jaringan nekrosis yang mengandung polipeptida dan asam amino. Selain itu, interaksi antar bakteri pada gigi nekrosis juga mempengaruhi pertumbuhan bakteri tertentu. Produk bakteri dapat menjadikan pasokan nutrisi untukjenis bakteri lain, namun bakteri tertentu malah dapat menghasilkan bakteriosin yang menghambat bakteri lain. Hal ini yang menentukan jenis bakteri yang ditemukan pada saluran akar gigi nekrosis., ${ }^{2,11,13}$

Berdasarkan penelitian ini, bakteri yang paling dominan berada di saluran akar gigi nekrosis adalah Actinomyces spp. yang merupakan bakteri anaerob fakultatif gram positif. Fakta ini berbeda dengan hasil penelitian yang dilakukan oleh Ercan $\mathrm{dkk}^{7}$ dan Saito $\mathrm{dkk}^{14}$ yang menyatakan bahwa jenis bakteri Peptostreptococcus merupakan bakteri yang paling dominan dari infeksi saluran akar. Pada penelitian Ercan dkk, ${ }^{7}$ bakteri Actinomyces spp. teridentifikasi sebanyak $7,1 \%$. Perbedaan jenis bakteri yang banyak ditemukan pada saluran akar gigi yang nekrosis dapat disebabkan oleh jumlah sampel yang diteliti serta metode identifikasi bakteri yang berbeda.

Bakteri Actinomyces spp. merupakan bakteri anaerob fakultatifgram positif yang memiliki bentuk basil. Koloni bakteri tersebut terdapat pada gigi dan sering terisolasi pada infeksi endodontik. Bakteri Actinomyces spp. juga merupakan suatu patogen yang sering ditemukan pada kasus perawatan endodontik yang berulang-ulang. Hal ini dihubungkan dengan prosedur debridement saluran akar yang tidak akurat dan perawatan endodontik yang tidak asepsis. ${ }^{9,15}$

Dari hasil penelitian ini, disimpulkan bahwa jenis bakteri yang paling dominan pada saluran akar gigi nekrosis adalah bakteri Actinomyces spp. Akan tetapi perlu dilakukan penelitian lanjut mengenai identifikasi bakteri gigi nekrosis berdasar lamanya gigi nekrosis dan uji sensitivitas antibiotik terhadap bakteri yang terdapat pada saluran akar gigi nekrosis.

\section{DAFTAR PUSTAKA}

1. Torabinejad M, Walton RE. Principles and practice of endodontics. $4^{\text {th }}$ Ed. Philadelphia: Saunders Company; 2009. p. 1,7,21, 28, 38-40, 49-56

2. Ingle JI, Bakland LK. Endodontics. $5^{\text {th }}$ Ed. London: BC. Decker; 2002. p. 25, 179-86

3. Roberson, Theodore MH, Harald O, Edward J. Sturdevant's art \& science of operative dentistry. $4^{\text {th }}$ Ed. Missouri: Mosby; 2002. p. 74

4. Kementerian Kesehatan Indonesia. Profil kesehatan Indonesia tahun 2010. Jakarta: Kementerian Kesehatan RI; 2011. hal. 42

5. Dinas Kesehatan Kota Makassar. Profil kesehatan Kota Makassar tahun 2007. Makassar: Pemeritahan Kota Makassar; 2008. hal. 41

6. Narayanan L, Vaishnavi C. Endodontic microbiology. J Conserv Dent 2010; 13(4): 233-9

7. Ercan E, Dalli M, Yavuz I, Ozekinci T. Investigation of microorganisme in infected dental root canals. Biotechnol Eq 2006; 20(2):166-72

8. Sassone LM, Fidel RA, Faveri M, Guerra R, Figueiredo L, Fidel SR, et al. A Microbiological profile of symptomatic teeth with primary endodontic infections. J Endod 2008; 34: 541-5

9. Jawetz E, Melnick JL, Adelberg E.A. Mikrobiologi kedokteran. Hartanto H. Edisi ke-23. Jakarta: EGC; 2007. hal. 238,245,311-3

10. Rani A, Chopra A. Isolation and identification of root canal bacteri from sympomatic nonvital teeth with periapical pathosis. J Endod 2006: 12-7

11. Baumgartner JC. Microbiologic aspects of endodontic infections. Can Dent Assoc J 2004; 32: 459-68

12. Figdor D, Sundqvist G. A big role for the very small - understanding the endodontic microbial flora. Austr Dent J Sup 2007;52: 38-51

13. Dougherty WJ, Watkins BJ, Baumgartner JC. Black-pigmented bacteria in coronal and apical segments of infected root canals. J Endod 1998; 24: 359-8

14. Saito D, Leonardo RT, Rodrigues JLM, Siu MT, Hofling JF, Goncalves RB. Identification of bacteria in endodontic infections by sequence analysis of $16 \mathrm{~S}$ rDNA clone libraries. J Med Microbiol 2006; 55:101-7

15. Peciuliene V, Maneliene R, Balcikonyte E, Drukteinis S, Vygandas R. Microorganisms in root canal infections: a review. Balt Dent J 2008; 10(1): 4-9 